Review

\title{
Current Perspectives of Biocontrol Agents for Management of Fusarium verticillioides and Its Fumonisin in Cereals-A Review
}

\author{
Deepa $\mathbf{N}^{1}\left(\mathbb{D}\right.$, Premila N. Achar ${ }^{2, *(\mathbb{D})}$ and Marikunte Y. Sreenivasa ${ }^{1, *}$ \\ 1 Department of Studies in Microbiology, University of Mysore, Mysuru 570 006, Karnataka, India; \\ deepanagraju@gmail.com \\ 2 Department of Molecular and Cellular Biology, Kennesaw State University, Kennesaw, GA 30144, USA \\ * Correspondence: pachar@kennesaw.edu (P.N.A.); mys@microbiology.uni-mysore.ac.in (M.Y.S.); \\ Tel.: +1-470-578-3524 (P.N.A.); +91-821-2419733 (M.Y.S.)
}

Citation: N, D.; Achar, P.N.;

Sreenivasa, M.Y. Current Perspectives of Biocontrol Agents for Management of Fusarium verticillioides and Its Fumonisin in Cereals-A Review. J. Fungi 2021, 7, 776. https://doi.org/ 10.3390/jof7090776

Academic Editor: Julio

Alberto Zygadlo

Received: 6 September 2021

Accepted: 17 September 2021

Published: 18 September 2021

Publisher's Note: MDPI stays neutral with regard to jurisdictional claims in published maps and institutional affiliations.

Copyright: (c) 2021 by the authors. Licensee MDPI, Basel, Switzerland. This article is an open access article distributed under the terms and conditions of the Creative Commons Attribution (CC BY) license (https:/ / creativecommons.org/licenses/by/ $4.0 /)$.

\begin{abstract}
Fusarium verticillioides is the most predominant fungal phytopathogen of cereals and it is posing great concern from a global perspective. The fungus is mainly associated with maize, rice, sorghum, wheat, sugarcane, banana, and asparagus and causes cob, stalk, ear, root, crown, top, and foot rot. F. verticillioides produces fumonisins as the major secondary metabolite along with trace levels of beauvericin, fusaric acid, fusarin C, gibberiliformin, and moniliformin. Being a potential carcinogen, fumonisins continue to receive major attention as they are common contaminants in cereals and its processed food products. The importance of elimination of $F$. verticillioides growth and its associated fumonisin from cereals cannot be overemphasized considering the significant health hazards associated with its consumption. Physical and chemical approaches have been shown to reduce fumonisin B1 concentrations among feeds and food products but have proved to be ineffective during the production process. Hence, biological control methods using microorganisms, plant extracts, antioxidants, essential oils, phenolic compounds, and other advanced technologies such as growing disease-resistant crops by applying genetic engineering, have become an effective alternative for managing F. verticillioides and its toxin. The different methods, challenges, and concerns regarding the biocontrol of $F$. verticillioides and production of fumonisin B1 have been addressed in the present review.
\end{abstract}

Keywords: fumonisin; biocontrol; phytopathogen; Fusarium; plant pathogens

\section{Introduction}

Mycotoxigenic contamination of feeds, cereals, and cereal-based food by Fusarium verticillioides adversely affects the health of humans and animals leading to a decline in the economy and international trade. Developed countries uphold food suppliers' and retailers' high standards by implementing regulatory controls involving good agricultural management practices, hazard analysis and critical control point (HACCP), addressing food safety. In addition, the application of selected physical treatments, chemicals, and biologically based strategies substantially reduce fumonisin contamination in cereals and cereal-based products [1]. In developing countries, governing measures are poorly enforced by farming communities. Certain methods such as hand-sorting of contaminated cereals has been practiced and seem to be partially effective, remaining as the last line of defense in reducing fumonisin and mycotoxin exposure [2].

Studies have shown that consumption of mycotoxin-contaminated cereals can affect the lungs, liver and kidneys in animals and cause wounds, skin lesions, and even lead to cancer in humans [3,4]. In horses, being fed with naturally contaminated corn, corn screenings, and corn-based feeds or intravenous injection of fumonisin leads to leukoencephalomalacia (LEM) [5]. Pulmonary edema syndrome (PES) and hydrothorax were 
observed in pigs on consumption of fumonisin-B1-contaminated corn screenings and through intravenous injections of fumonisin, respectively [6]. Voss et al. [7] reported that hydrolyzed FB1 (HFB1) interferes with sphingolipid metabolism without causing any neural tube defects in a mouse model. When the blood-brain barrier was permeated in young carp, neurotoxicity due to FB1 was reported [8]. On consumption of the corn associated with fumonisins or contaminated with $F$. verticillioides, reports indicate large numbers of cases of esophageal cancer, among humans, in Transkei, South Africa [9], Northern Italy [10], Linxhian, China [11], the south-eastern United States, and Golestan, Iran [12]. The International Agency for Research on Cancer (IARC) characterized FB1 as a possible group 2B carcinogen, which can cause toxicity in humans and several animals like rats, horse, mice, and rabbits [13].

\section{Worldwide Association of F. verticillioides}

Fusarium verticillioides distribution is ubiquitous, mainly associated with maize [1,14], rice [15-17], sugarcane [18], wheat [19], banana [20], asparagus [21,22], and sorghum [23]. Rocha et al. [24] screened maize grain samples from Brazil and documented nearly $96 \%$ frequency of F. verticillioides. The highest incidence of F. verticillioides was reported in poultry and animal feed made up of wheat bran and maize pellets [25]. Among the 135 cereal samples collected from southern India, 69 were associated with Fusarium contamination, among which 51 samples showed F. verticillioides [26]. In southern Europe, Italy, and Iran, F. verticillioides was the predominant species associated with maize grain samples [27-29]. Among 103 Fusarium species screened from the cereal samples collected from Karnataka, India, 64 isolates were found to be fumonisin-producing F. verticillioides [30].

A major focus by scientists across the globe is on mycotoxigenic fungi since they are global contaminants of cereals and cereal-based food products [3]. Mycotoxins such as fumonisin B produced by F. verticillioides in cereals, is categorized into FB1, FB2, FB3, and FB4, based on the structure and hydroxyl group [3]. Fumonisin B1, the most predominant and toxic mycotoxin accounts for $70 \%$ of the total fumonisins and receives worldwide attention compared to FB2, FB3, and FB4 [31] (Table 1). FB1 toxicity seems to be complex resulting in disruption of de novo biosynthesis of ceramide-deregulating sphingolipid complex [32]. Exposure to FB1 toxin among humans and animals leads to the accumulation of spingoid bases, increased phosphate adducts, and reduced ceramide concentrations, resulting in apoptosis, cytotoxicity, cell proliferation [33], neural tube defects, hepatocarcinoma, carcinogenicity, and DNA damage [34].

Table 1. Diseases and toxins produced by F. verticillioides in different cereal crops.

\begin{tabular}{|c|c|c|c|}
\hline Serial Number & Crop & Disease & Toxins \\
\hline 1. & $\begin{array}{l}\text { Corn/Maize } \\
\text { (Zea mays) }\end{array}$ & $\begin{array}{l}\text { Fusarium ear rot, stalk rot, } \\
\text { kernel rot, root rot, seed rot, } \\
\text { seedling blight, seedling root rot }\end{array}$ & FB1, FB2, and FB3 \\
\hline 2. & $\begin{array}{l}\text { Cultivated wild } \\
\text { rice } \\
\text { (Zizania palustris) }\end{array}$ & Scab & FB1, FB2 \\
\hline 3. & $\begin{array}{c}\text { Oats } \\
\text { (Avens sativa) }\end{array}$ & $\begin{array}{l}\text { Fusarium foot rot, snow mold, } \\
\text { seedling blight, head blight }\end{array}$ & FB1, FB2 \\
\hline 4. & $\begin{array}{l}\text { Pearl millet } \\
\text { (Pennisetum } \\
\text { glauccum) }\end{array}$ & Top rot & FB2, FB1 \\
\hline 5. & $\begin{array}{c}\text { Rice } \\
(\text { Oryza sativa })\end{array}$ & $\begin{array}{l}\text { Seedling blight, water mold, } \\
\text { root rot, pecky rice (kernel } \\
\text { spotting) }\end{array}$ & FB1, FB2, FB3 \\
\hline
\end{tabular}


Table 1. Cont.

\begin{tabular}{cccc}
\hline Serial Number & Crop & Disease & Toxins \\
\hline 6. & $\begin{array}{c}\text { Sorghum } \\
\text { (Sorghum bicolor })\end{array}$ & $\begin{array}{c}\text { Damping off and seed rot, } \\
\text { Fusarium wilt head blight, root } \\
\text { and stalk rot, twisted top, } \\
\text { seedling blight, seed rot }\end{array}$ & FB2, FB1 \\
\hline 7. & $\begin{array}{c}\text { Sugarcane } \\
\text { (Saccharum spp.) }\end{array}$ & $\begin{array}{c}\text { Fusarium stem rot, pokkah } \\
\text { baeng, wilt; }\end{array}$ & FB1, FB2 \\
(Theat & $\begin{array}{c}\text { Black point (kernel smudge), } \\
\text { head blight (scab), } \\
\text { root, crown, and foot rot, } \\
\text { pink snow mold; }\end{array}$ & FB1, FB2 \\
\hline Source: www.apsnet.org/online/common/search.asp accessed on 1 August 2018. \\
\end{tabular}

The fumonisin-producing $F$. verticillioides strains were initially confirmed through various PCR methods $[35,36]$, such as multiplex PCR and nested PCR which showed direct association of fumonisin with cereals, pure cultures, and plant parts. Both speciesspecific and fumonisin-specific genes were detected in a single test run in case of multiplex PCR [37]. While nested PCR involved two test runs, in which the first test run with species-specific primer product, served as DNA for the second test run with different primer for fumonisin [38]. Chromatographic techniques, such as high-performance liquid chromatography [39] and liquid chromatography mass spectrometry [40] were used to quantify FB1 toxin associated with cereal samples. According to the Food and Agriculture Organization (FAO) and the World Health Organization (WHO), tolerable maximum intake for fumonisins has been set as $2 \mu \mathrm{g} / \mathrm{Kg} \cdot \mathrm{bw} /$ day based on lack of any observed adverse effects for nephrotoxicity in male rats [41].

\section{Management of $\boldsymbol{F}$. verticillioides}

Many studies have been reported on various prevention strategies and pre-harvest control methods such as disease-resistant varieties, biocontrol agents such as microorganisms, and plant extracts against growth and toxin production by Fusarium species [42,43]. Several researchers examined post-harvest removal of fumonisin from food commodities by physical, chemical, and modest biological control methods $[44,45]$. Proper agricultural practices need to be maintained during pre-harvest and post-harvest to minimize the growth of $F$. verticillioides and its toxin production in cereals. Fumonisins are managed by prevention of F. verticillioides infection, in addition to the monitoring of the contaminants, and their detoxification [46].

\section{Physical Methods for Management of F. verticillioides}

Physical methods comprise of the separation of damaged or contaminated crops from healthy ones including methods like sorting, sieve cleaning, density segregation, washing, de-hulling, and steeping. Drying of grains to lower the moisture content is one of the preliminary and safest method against growth of molds and grain can be safely stored for a longer duration [47]. In addition, separation of infected and physically damaged grains from the healthy ones is an efficient and feasible method of reducing mycotoxin contamination [48]. Heating, another physical factor, which is a procedure carried out during various food processing at temperatures $>150{ }^{\circ} \mathrm{C}$, degrades the stability of fumonisin, and hence, it is considered as a good method for the removal of mycotoxin through leaching [49]. A novel physical method, of recent interest, is use of non-thermal techniques such as cold plasma for fungal and mycotoxin removal. Cold plasma is an ionized gas containing partially ionized atoms with zero net charge [50]. Another emerging non-thermal technique used for removal of mycotoxins, is the photocatalytic detoxification of mycotoxins in food. This method comprises of chemical reactions induced by absorption of photons by a solid photocatalyst, resulting in oxidation or reduction reactions on the surface of photocatalytic 
materials that produce free radicals which interact with contaminants such as fumonisin, and help to degrade or reduce the toxin [51].

Furthermore, irradiation such as by X-rays, gamma rays, or accelerated electrons is reported as an alternative method to control mycotoxin-producing molds in certain food products [52]. Maize and sorghum grain samples with a weight of $250 \mathrm{~g}$ were exposed to $2.5,5.0,7.5$, and $10.0 \mathrm{kGy}$ of gamma irradiation for evaluation of $F$. verticillioides incidence $(\%)$ and fumonisin levels at regular intervals of $0,30,60$, and 90 days of storage [53]. Results revealed that on day 0 , the incidence of Fusarium species was 48 and $38 \%$, respectively, in maize and sorghum samples and there was a gradual decrease in the incidence of Fusarium species at 2.5 and $5.0 \mathrm{kGy}$ doses of gamma irradiation after 30, 60, and 90 days storage. Deepthi et al. [54] reported that ionizing radiation at $7.5 \mathrm{kGy}$ was lethal for Fusarium species growth and its FB1 production. In addition, they also observed that $\gamma$-radiation, above $7.5 \mathrm{kGy}$, effectively prevented Fusarium growth and minimized the exposure of animals and humans to fumonisin. The FAO, IAEA, and WHO stated that irradiated foods with less than $10 \mathrm{kGy}$ doses are considered to be safe and nutritionally adequate when produced under established good manufacturing practices [55].

\section{Chemical Methods for Management of $F$. verticillioides}

Chemical methods to decontaminate fumonisin in maize and maize products have also been previously reported. Fumonisin is a stable molecule; hence, its destruction is challenging [56]. Munkvold et al. [56] reported a significant reduction of FB1 of up to 95\% by treating contaminated maize seeds with $\mathrm{Ca}(\mathrm{OH})_{2}$. Lu et al. [57] reported fumonisin degradation using sodium bicarbonate and hydrogen peroxide. Fructose, in the presence of a primary amine and water $(\mathrm{pH}>7)$, removes the preliminary amine group from fumonisin through non-enzymatic browning and has been reported to cause a drastic reduction of FB1 in maize grains and eventually in rat models. In this study, it was reported that removal of the amine group caused structural changes in fumonisin and in its ability to cause cancer in rat models [58]. Combination of ammonization and high temperature leads to fumonisin detoxification [59]. Use of chemicals methods, seem to decrease fumonisin levels significantly, compared to physical methods such as air drying of cereals or grains. This observation was reported by Scott [60] who found that treatment of cereals or grains with $2 \%$ ammonium hydroxide at $50{ }^{\circ} \mathrm{C}$ decreases fumonisin concentration to $89 \%$, compared to four days of air drying which reduced the toxin by only $32 \%$.

Consumption of maize and maize-based products, in large amounts, may result in high risk of exposure to fumonisin. Previous studies have reported that nixtamalization (alkaline cooking) of maize grains results in hydrolyzation of fumonisin and lowers its toxicity $[61,62]$. A study in Central America, reported that the nixtamalization of maize grains during the production of tortilla, significantly reduced the fumonisin concentration. HFB1 (hydrolyzed fumonisin) was detected in staple food such as commercial masa and tortilla chips [63]. Another study documented a 100\% reduction of fumonisin in contaminated maize by eradication of the mutagenic potential of maize extracts, when subjected to a modified nixtamalization procedure [64]. On the contrary, Voss et al. [65], suggested that chemical procedures such as nixtamalization, reduced only the detectable fumonisin levels but did not result in toxicity reduction. Most importantly, detoxification methods should be capable of removing all traces of active toxin, must not leave any hazardous chemical residues in the treated samples, and above all, should not compromise the nutritional value of the food [66].

\section{Limitations of Physical and Chemical Methods}

Many of the physical and chemical methods used to minimize fumonisin B1 concentrations in cereals or cereal-based foods have proved to be either ineffective or difficult to practice in the food production process $[67,68]$. The detoxification methods of fumonisin, must be cost effective, simple, and easily applied by farmers. While physical methods were found to have low efficacy and less specificity, chemical methods were found to be expen- 
sive, and affect the quality of food products by producing toxic derivatives and decreasing the nutritional value of the food $[48,69]$. Certain chemical compounds used as antifungal agents were not biodegradable and resulted in contaminated water and soil [70,71]. Prolonged use of chemical treatments during cultivation of grains and cereals, has enabled the hosts to establish resistance against the fungal pathogens. Increased demand for the use of chemicals in agriculture to combat pathogens has escalated toxic residues in food crops [72]. Hence, there is a great demand for the alternative and safe methods to control $F$. verticillioides and fumonisin contamination in cereals.

\section{Management of F. verticillioides by Natural Clay}

Natural clay adsorbents have been considered as Generally Recognized as Safe (GRAS) by the Food and Drug Administration, USA [73]. Natural clay adsorbs mycotoxins in food and its products by detoxifying the contaminated food during processing stages [74]. Montmorillonite clay is more significant than other clay minerals due to its large surface area and molecular structure that increases its adsorbing ability when wet. Montmorillonite clay at a low dose of $1.5 \mathrm{~g}$ and a high dose of $3 \mathrm{~g} /$ per day, through adsorption, effectively reduces FB1 in aqueous solution in vitro, and in human and animal models in vivo respectively. The adsorption is saturable and occurs largely within the interlaminar regions of the clay [75]. In addition, it was reported that a combination of clay and modified yeast cell extracts enhances adsorption of multiple mycotoxins [76]. Natural clay has also been demonstrated to be suitable for commercial use by the Selection Committee on GRAS substances (SCOGS) since they could be applied effectively and economically in the food and feed industries [77]. However, application of clay minerals often requires high levels to be included into animal feed; interaction of natural clays with food and gut-based nutrients remains unclear, and the possibility of accumulation of dioxin in animals remains a concern [1].

\section{Biological Control of $F$. verticillioides}

Biological control methods can be employed to minimize the contamination of fumonisin produced by F. verticillioides. According to Alberts et al. [1], simple pest control strategies were found to have a positive impact on food security and safety, especially in the rural areas where maize is a staple diet. Simple and effective biological strategies have attracted the attention of farmers throughout the world [78]. F. verticillioides being a phytopathogen, is mainly associated with cereals such as maize and sorghum and is largely responsible for the economic losses worldwide [79]. Currently, minimizing the soil-borne pathogens by application of synthetic fungicides or chemical pesticides has been challenged by biological approaches that play a major role in sustainable agriculture. Such biocontrol methods can be effectively adopted by binding the biocontrol agents through plant parts such as roots and seeds, and/or the soil against the target pathogen (Figure 1). Probiotics, non-toxigenic strains of fungi, plant-growth-promoting rhizobacteria, antioxidants, plant extracts, genetic engineering, and disease-resistant crop varieties have been used as biological management strategies against fumonisin-producing $F$. verticillioides (Figure 2). 


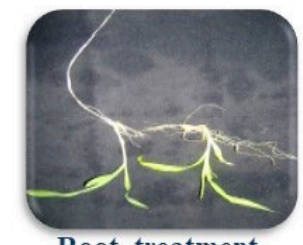

Root treatment with biocontrol agents

Fungal-resistant Varieties as biocontrol

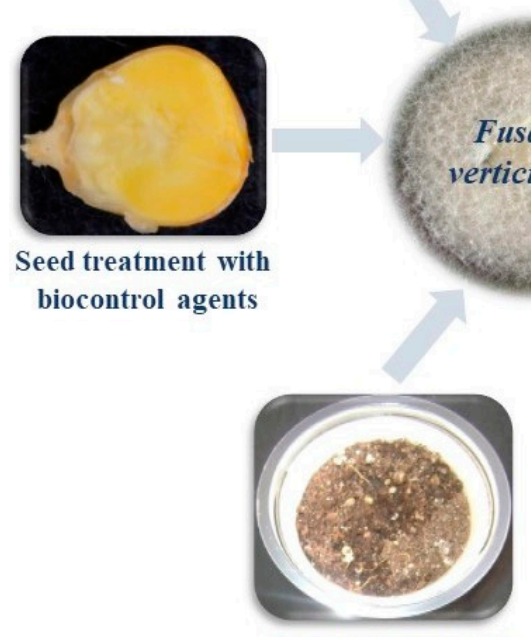

Fusarium erticillioides

Soil treatment with biocontrol agents

Figure 1. Treatment of plant parts, soil and use of resistant varieties, as biocontrol methods against F. verticillioides.

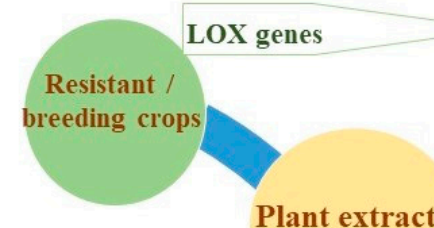

Essential oils

Alkaloid extract

Phenolic compounds

Aqueous extract

Solvent extract

\section{Biocontrol of}

Fusarium verticillioides

Probiotics

Microorganisms Atoxigenic strains

PGPR

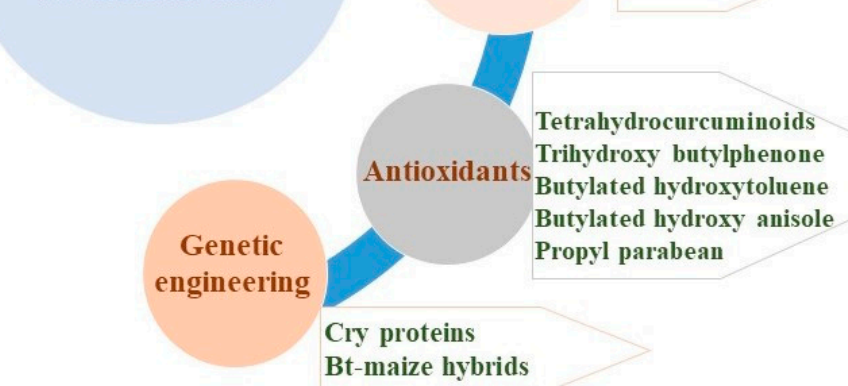

Figure 2. Use of biological control agents against F. verticillioides. PGPR, plant-growth-promoting rhizobacteria; LOX genes, lysyl oxidase genes; Bt-maize, Bacillus thuringiensis maize. 


\subsection{Microorganisms as Biocontrol Agents}

The application of microorganisms that have the ability to colonize infected plant parts under certain appropriate and compatible environmental conditions, has become the recent trend in minimizing the growth of pathogens and toxin production $[72,80]$.

\subsubsection{Bacteria as Biocontrol Agents}

The American Food and Drug Administration considers Bacillus subtilis as Generally Regarded as Safe (GRAS), since the organism can be easily cultured and genetically manipulated as it appropriately fits into the industrial processes. B. subtilis, an endophytic bacterium, and an ecological homologue with F. verticillioides in maize, reduced nearly $50 \%$ of FB1 accumulation during vertical transmission which spreads from plant to cob [44]. Another report indicated that B. mojavensis, the fusaric-acid-resistant mutant strain, the wild type, showed biocontrol potential against $F$. verticillioides [81]. Furthermore, F. verticillioides in vitro, has also shown its antagonistic properties against $B$. amyloliquefaciens without causing any changes in the rhizospheric region [82]. Microorganisms such as Exophiala spinifera (ATCC 74269), Sphingopyxis macrogoltabida (MTA 144), Bacterium so (ATCC 55552), and Rhinocladiella atrovirens (ATCC 74270) are capable of minimizing the production of FB1 in F. verticillioides [83-88] (Table 2).

It was reported that in greenhouse conditions, B. amyloliquefaciens and Enterobacter hormacchei, at a concentration of $10^{9} \mathrm{CFU} \mathrm{mL} \mathrm{m}^{-1}$ reduced the infection of maize grains against $F$. verticillioides and fumonisin production in the soil, thereby improving the quality of maize grains [82]. In greenhouse trials, root applications of B. subtilis $\left(10^{8}\right.$ and $\left.10^{7} \mathrm{CFU} / \mathrm{mL}\right)$, against $F$. verticillioides has become the potential biocontrol method due to the ability of $B$. subtilis to reduce the endorhizosphere and rhizoplane colonization with the pathogen [89]. Root infection of maize seedlings by F. verticillioides was minimized followed by B. amyloliquefaciens treatments, and it was reported as an effective preventive measure against horizontal transmission (transmission between neighboring plants) of pathogens, without affecting the normal plant growth [90] (Table 3).

Table 2. In vitro effect of biocontrol agents on growth (\%) and development of toxigenic F. verticillioides.

\begin{tabular}{|c|c|c|c|c|c|}
\hline Serial Number & Test Organism & $\begin{array}{l}\text { Methods Used for } \\
\text { Screening }\end{array}$ & $\begin{array}{l}\text { Targeted Feature } \\
\text { of F. verticillioides }\end{array}$ & $\begin{array}{l}\text { Percent of } \\
\text { Reduction }\end{array}$ & Reference \\
\hline \multicolumn{6}{|c|}{ Microorganisms } \\
\hline 1. & Bacillus subtilis & Antifungal activity & Fungal growth & $50 \%$ & [91] \\
\hline 2. & Lactobacillus rhamnococcus & Antifungal activity & Mold growth & $78-92 \%$ & \multirow{2}{*}[90,92]{} \\
\hline 3. & Saccharomyces cerevisiae & Antifungal activity & $\begin{array}{l}\text { Mold growth and } \\
\text { FB1 }\end{array}$ & $77-89 \%$ & \\
\hline 4. & Pediococcus pentosaceus & $\begin{array}{l}\text { Antifungal activity } \\
\text { and spectrum }\end{array}$ & Zone of inhibition & $89 \%$ & [93] \\
\hline 5. & $\begin{array}{c}\text { Enterococcus casseliflavus } \\
\text { M4A }\end{array}$ & Antifungal activity & Fungal growth & $100 \%$ & [94] \\
\hline 6. & Trichoderma viridae & Antifungal activity & Zone of inhibition & $90 \%$ & \multirow{2}{*}[70,95,96]{} \\
\hline 7. & Trichoderma harzianum & Antifungal activity & Zone of inhibition & $<70 \%$ & \\
\hline 8. & Pseudomonas solanaceacum & Antifungal activity & Zone of inhibition & $70 \%$ & [81] \\
\hline 9. & $\begin{array}{l}\text { Mixture of E. cloacae and } M . \\
\text { oleovorans; } \\
\text { mixture of P. solanaceacum } \\
\text { and B. subtilis }\end{array}$ & Antibiosis & Root colonization & $50 \%$ & [87] \\
\hline
\end{tabular}


Table 2. Cont.

\begin{tabular}{|c|c|c|c|c|c|}
\hline Serial Number & Test Organism & $\begin{array}{l}\text { Methods Used for } \\
\text { Screening }\end{array}$ & $\begin{array}{l}\text { Targeted Feature } \\
\text { of F. verticillioides }\end{array}$ & $\begin{array}{l}\text { Percent of } \\
\text { Reduction }\end{array}$ & Reference \\
\hline & & ntioxidants & & & \\
\hline 10. & $\begin{array}{l}\text { Butylated hydroxyanisole } \\
\text { (BHA) }\end{array}$ & \multirow{4}{*}{ Water activity } & \multirow{4}{*}{ Mycelial growth } & $94-98 \%$ & \multirow{2}{*}[68]{} \\
\hline 11. & Propylparabean (PP) & & & $100 \%$ & \\
\hline 12. & $\begin{array}{c}\text { Trihydroxybutyrophenone } \\
\text { (THBP) }\end{array}$ & & & $>85 \%$ & \multirow{2}{*}{ [97] } \\
\hline 13. & $\begin{array}{l}\text { Butylated hydroxytoluene } \\
\text { (BHT) }\end{array}$ & & & $95 \%$ & \\
\hline 14. & $\begin{array}{l}\text { Tetrahydrocurcuminoids } \\
\text { (THC) }\end{array}$ & Antifungal activity & $\begin{array}{l}\text { Fungal conidial } \\
\text { growth }\end{array}$ & $100 \%$ & [98] \\
\hline \multicolumn{6}{|c|}{ Phenolic Compounds and Plant Extracts } \\
\hline 15. & $\begin{array}{l}\text { Geranial, eugenol, and } \\
\text { singerone from Zingiber } \\
\text { officinale }\end{array}$ & $\begin{array}{l}\text { Poisoned food } \\
\text { technique }\end{array}$ & mycelial growth & $100 \%$ & [99] \\
\hline 16. & $\begin{array}{c}\text { Carvacrol, eugenol, } \\
\text { 2-hexanal from oregano, } \\
\text { thyme, cinnamon, clove, } \\
\text { fruits, and vegetables }\end{array}$ & Antifungal activity & $\begin{array}{l}\text { Conidial } \\
\text { germination and } \\
\text { mycelial growth }\end{array}$ & $37-97 \%$ & [100] \\
\hline 17. & $\begin{array}{l}\text { Chitin-binding protein from } \\
\text { Ginko biloba, }\end{array}$ & Antifungal activity & Mycelial growth & $>50 \%$ & {$[101]$} \\
\hline 18. & Vanillic acid and caffeic acid & Antifungal activity & Fungal growth & $\begin{array}{r}80 \% \\
100 \%\end{array}$ & {$[102,103]$} \\
\hline 19. & $\begin{array}{l}\text { Chlorophorin, iroko, } \\
\text { maakianin, and ferulic acid }\end{array}$ & $\begin{array}{l}\text { Agar-well } \\
\text { diffusion and } \\
\text { HPLC }\end{array}$ & $\begin{array}{l}\text { Fungal growth and } \\
\text { FB1 }\end{array}$ & $88-94 \%$ & [103] \\
\hline 20. & $\begin{array}{l}\text { Flavonoids, phenolic acid, } \\
\text { and terpine-rich ethanol } \\
\text { extracts from Equisetum } \\
\text { arvense and Stevia rebaudiana }\end{array}$ & Antifungal activity & Fungal growth & $79 \%$ & [104] \\
\hline 21. & $\begin{array}{l}\text { Aqueous extract, methanol } \\
\text { extract, and alkaloid extract } \\
\text { from Prosopis juliflora }\end{array}$ & $\begin{array}{l}\text { Poisoned food } \\
\text { technique }\end{array}$ & Mycelial growth & $100 \%$ & [105] \\
\hline 22. & $\begin{array}{l}\text { 1,8-Cineole from Rosnainum } \\
\text { officinalis }\end{array}$ & & $\begin{array}{l}\text { Conidial } \\
\text { production }\end{array}$ & $53.48 \%$ & \\
\hline 23. & $\begin{array}{l}\text { Eugenol, methyl eugenol, } \\
\text { and tumerone from } \\
\text { Syzygium aromaticum, } \\
\text { Pimenta dioica, and C. longa }\end{array}$ & Antifungal activity & Fungal growth & $40-80 \%$ & [106] \\
\hline
\end{tabular}


Table 3. In planta effect of bacteria as biocontrol agents against $F$. verticillioides in maize.

\begin{tabular}{|c|c|c|c|c|}
\hline $\begin{array}{l}\text { Serial } \\
\text { Number }\end{array}$ & $\begin{array}{c}\text { Plant Parts Treated } \\
\text { with Biocontrol } \\
\text { Agents }\end{array}$ & Test Organisms & $\begin{array}{l}\text { Targeted } \\
\text { Feature }\end{array}$ & $\begin{array}{c}\text { Percent } \\
\text { Inhibition }\end{array}$ \\
\hline 1. & Maize plant & Bacillus subtilis & Colonization & $28-78 \%$ \\
\hline 2. & Maize seedling stalk & $\begin{array}{c}\text { Bacillus } \\
\text { mojavensis }\end{array}$ & Colonization & $24-58 \%$ \\
\hline 3. & Seed & $\begin{array}{c}\text { Bacillus } \\
\text { amyloliquifaciens }\end{array}$ & Fungal growth & \multirow{3}{*}{$>82 \%$} \\
\hline 4. & Seed & $\begin{array}{c}\text { Microbacterium } \\
\text { oleovarans }\end{array}$ & Maize infection & \\
\hline 5. & Seed & $\begin{array}{c}\text { Enterobacter } \\
\text { hormacchei }\end{array}$ & Fungal growth & \\
\hline 6. & Maize roots & $\begin{array}{c}\text { Enterobacter } \\
\text { cloacae }\end{array}$ & $\begin{array}{l}\text { Colonization in } \\
\text { roots }\end{array}$ & $<50 \%$ \\
\hline 7. & Maize stalk & $\begin{array}{c}\text { Clonostachys } \\
\text { rosae }\end{array}$ & Colonization & $50 \%$ \\
\hline 8. & \multirow{2}{*}{$\begin{array}{l}\text { Rhizoplane and } \\
\text { endorhizosphere } \\
\text { region }\end{array}$} & $\begin{array}{l}\text { Arthrobacter } \\
\text { globiformis }\end{array}$ & $\begin{array}{c}\text { Root } \\
\text { colonization }\end{array}$ & $69-80 \%$ \\
\hline 9. & & $\begin{array}{l}\text { Azotobacter } \\
\text { armeniacus }\end{array}$ & $\begin{array}{c}\text { Root } \\
\text { colonization }\end{array}$ & $56-75 \%$ \\
\hline
\end{tabular}

\subsubsection{Probiotics as Biocontrol Agent}

Furthermore, lactic acid bacteria have been applied as a safe biocontrol agent to minimize the growth and production of $F$. verticillioides and fumonisin production. Certain in vitro studies have shown the inhibitory potential of Saccharomyces cerevisiae and Lactobacillus rhamnous against $F$. verticillioides growth [92]. Reports of in vivo studies indicated elimination of FB1 content in mature mice administered with the biocontrol agent, S. cerevisiae [93]. In another report, S. cerevisiae as a biocontrol agent, was observed to control the growth of F. verticillioides and FB1 production in cereals [87]. Pediococcus pentosaceus, with a GRAS status, is widely used as a biocontrol organism in food fermentation and ensilage quality improvement. Additionally, the supernatant of P. pentosaceus exhibited antifungal activity thereby inhibiting growth of both F. proliferatum and F. verticillioides [107]. Recently Enterococcus casseliflavus M4A strain was reported to be a promising tool for biocontrol of F. verticillioides in storage maize grain silos. Combination of volatile organic compounds diacetyl and acetic acid produced by Enterococcus casseliflavus M4A strain completely inhibited $F$. verticillioides growth and acetoin significantly $(88.75 \%)$ reduced FB1 biosynthesis [94] (Tables 2 and 4).

\subsubsection{Fungi as Biocontrol Agents}

Among the fungi, Trichoderma species are considered as an effective biocontrol agent against $F$. verticillioides due to their ability to produce extracellular lytic enzymes [47]. Harmosa et al. conducted in vitro and in planta studies in maize and suggested by GRAS status that, T. harzianum and T. viridae, effectively reduced the growth of $F$. verticillioides and its fumonisin production by producing extracellular enzymes, volatile compounds, and antibiotics $[95,108]$ (Tables 2 and 3). Trichoderma species were also applied as postharvest biocontrol agents, which reduced the colonization of $F$. verticillioides and its toxin accumulation in corn during storage [96] (Table 2).

\subsubsection{PGPR as Biocontrol Agents}

Naturally occurring bacterial species Azotobacter and Arthrobacter were found to be prevalent and predominant mainly in the rhizoplane and endorhizosphere of maize- 
growing areas [91]. Enterobacter cloacae has also been reported as a noteworthy biocontrol agent against $F$. verticillioides during root colonization of maize crop [109]. Biological control potentials of bacteria in mixed cultures of E. cloacae, Microbacterium eoleovorans, $P$. solanacearum, and B. subtilis have shown synergistic activities by prevention and reduction of vertical transmission and colonization of roots by F. verticillioides in maize seed [87] (Table 2). Other bacterial species, such as Pseudomonas solanacearum, Azotobacter armeniacus, and Arthrobacter globiformis and rhizobacterial strains of Bacillus species were all found to exhibit potent in vitro antifungal activities as seed inoculants against F. verticillioides, thereby reducing its growth and FB1 production in the endorhizosphere and rhizoplane region of the maize root $[68,91]$ (Table 2$)$.

\subsubsection{Mycoviruses as Biocontrol Agents}

Currently, the application of mycoviruses as biocontrol agents both in vitro and in vivo is in great demand. Mycoviruses induce hypovirulence among host fungi as they lack extracellular transmission routes [110]. Three different mycoviruses FgV1, FgV2, and FgV3 induced hypovirulence and caused latent infections involving the role of RNAi among Fusarium species [111].

\subsubsection{Non-Toxigenic Strains as Biocontrol Agents}

Other strategies have also been used for biological control against Fusarium species. Non-pathogenic Fusarium strains have been moderately applied as biocontrol agents in suppressing the growth of toxigenic strains F. proliferatum and F. verticillioides in maize [112]. The gene silencing technique has been applied as a biocontrol strategy by deleting ZFR1 in F. verticillioides. This method affects fumonisin biosynthesis and regulates the sugar transporter genes during the formation of kernel colonization, resulting in minimized growth of maize endosperm; development of the endosperm plays a major role in biosynthesis of fumonisin in maize grain [113].

\subsection{Antioxidants as Biocontrol Agents}

Antioxidants, namely propylparaben (PP) and butylated hydroxyanisole (BHA), are considered GRAS by the FDA, and they are used as preservatives in certain food and cosmetic industries [114]. Under respective in vitro conditions, both BHA and PP were observed to suppress the growth of F. verticillioides and F. proliferatum [115], indicating their potential as biological control entities. Similarly, in a dose-response study, a 77\% reduction of F. verticillioides was reported with 10-100-fold doses of BHA/PP (500 $\mu \mathrm{g} / \mathrm{g}$ ) at water activity (0.95) for a period of 28 days [116]. Reynoso et al. [117] reported a higher percentage of reduction in fumonisin production during a combinational treatment of BHA and PP over other antioxidants, butylated hydroxytoluene (BHT) and trihydroxybutyrophenone (THBP) [97]. Another antioxidant, tetrahydrocurcuminoids (THC), and its related molecules extracted from non-toxic plant, Curcoma longa, was also found to suppress FB1 production in vitro [98]. Biosynthesis of FB1 from F. verticillioides was strongly inhibited by 3,6,7-trihydroxy- $\alpha$-tetralone (TT) extracted from Phoma moricola at $200 \mu \mathrm{g} / \mathrm{mL}$ concentration. TT is strongly active against the enzyme polyketide synthase as antimycotoxin, which could be explored as an eco-friendly method for managing mycotoxin contamination in food and feed stuffs [118] (Tables 2 and 4). 
Table 4. Effect of biocontrol agents on the reduction of fumonisin B1 production by F. verticillioides.

\begin{tabular}{|c|c|c|c|c|c|}
\hline Serial Number & Biocontrol Agents & Detection Method & $\begin{array}{l}\text { Percent of FB1 } \\
\text { Reduction }\end{array}$ & Level of Study & Reference \\
\hline & & Microorganisms & & & \\
\hline 1. & Bacillus subtilis & HPLC & $50 \%$ & In vitro & [87] \\
\hline 2. & Bacillus amyloliquifaciens & HPLC & \multirow{3}{*}{$>70 \%$} & Field study & \multirow{3}{*}[82,89]{} \\
\hline 3. & Microbacterium oleovarans & HPLC & & Field study & \\
\hline 4. & Enterobacter hormacchei & HPLC & & Field study & \\
\hline 5. & Lactobacillus rhamnococcus & HPLC & $78-92 \%$ & In vitro & \multirow{2}{*}[90,92]{} \\
\hline 6. & Saccharomyces cerevisiae & HPLC & $77-89 \%$ & In vitro & \\
\hline 7. & Pseudomonas solanaceacum & HPLC & $70-100 \%$ & In vitro & {$[68,81,87]$} \\
\hline 8. & $\begin{array}{l}\text { Mixture of E. cloacae/M. oleovorans; } \\
\text { mixture of P. solanaceacum/B. subtilis }\end{array}$ & HPLC & $100 \%$ & Field study & [91] \\
\hline & & Antioxidants & & & \\
\hline 9. & Butylated hydroxyanisole (BHA) & \multirow{4}{*}{ HPLC } & $100 \%$ & \multirow{4}{*}{ In vitro } & \multirow{2}{*}[68,117]{} \\
\hline 10. & Propylparabean (PP) & & $94-98 \%$ & & \\
\hline 11. & Trihydroxybutyrophenone (THBP) & & \multirow{2}{*}{$94-98 \%$} & & \multirow{2}{*}{ [97] } \\
\hline 12. & Butylated hydroxytoluene (BHT) & & & & \\
\hline 13. & 3,6,7-trihydroxy- $\alpha$-tetralone (TT) & HPLC & $>95 \%$ & In vitro & [118] \\
\hline \multicolumn{6}{|c|}{ Phenolic Compounds and Plant Extracts } \\
\hline 14. & Ferulic acid & HPLC & $98-100 \%$ & In vitro & [103] \\
\hline 15. & Vanillic acid, and caffeic acid & HPLC & $98-100 \%$ & In vitro & [102] \\
\hline 16. & Acetonin & HPLC & $88.75 \%$ & In vitro & [94] \\
\hline 17. & Acetone extract & HPLC & $96 \%$ & In vitro & [119] \\
\hline
\end{tabular}

\subsection{Plant Extracts as Biocontrol Agents}

Antifungal assays of plant extracts, and phenolic compounds from plants have been studied for long time, and these compounds have been identified as inhibiting the growth of $F$. verticillioides and suppressing fumonisin production. Aqueous and methanol extracts of the plant Prosopis juliflora inhibited the growth of F. verticillioides by $50 \%$ and $65 \%$ at $400 \mu \mathrm{g} \mathrm{mL}^{-1}$, respectively, whereas alkaloid extract of $P$. juliflora completely inhibited the growth of F. verticillioides at $300 \mu \mathrm{g} \mathrm{mL}^{-1}$ [105]. Recently, Tagetes erecta methanol extract from leaves, flowers, and roots of the plant were found to inhibit $F$. verticillioides growth by more than $65 \%$ after 7 days of incubation [108] Combination of Combretum erythrophyllum and Quercus acutissima acetone extract exhibited $96 \%$ inhibition against $F$. verticillioides growth [119]. In addition, F. verticillioides growth was also inhibited by $34 \%$ with highly potent betel leaf extract at $1000 \mathrm{ppm}$ concentration [120,121]. In another interesting report, incidence of $F$. verticillioides was lowered from $40 \%$ to $25 \%$ by storing maize in bamboo granaries instead of on cement floors; the bamboo granaries served as a biocontrol agent [122]. Phenolic compounds, namely, thymol, carvacrol, and eugenol, were identified to be the most active antifumonisin compounds among 10 natural phenolic compounds tested [120]. A chitin-binding protein from Ginko biloba and a polygalacturonase-inhibiting protein from Arabidopsis thaliana, inhibited growth of fumonisin-producing F. verticillioides [101,123]. Similarly, phenolic compounds such as caffeic and vanillic acid were observed to decrease the growth F. proliferatum and F. verticillioides and FB1 production in maize [124]. The authors, in their in vitro studies, observed an increase in concentration of phenolic compounds, such as caffeic acid and vanillic acid, which completely inhibited the growth of fungus and FB1 production; however, the growth inhibition (\%) of vanillic acid was more effective than caffeic acid [102]. In addition to vanillic acid and caffeic acid, iroko, chlorophorin, maakianin, and ferulic have also been reported to inhibit the growth of $F$. verticillioides and the biosynthesis of fumonisin B1 [103]. Non-toxic plants extract such as flavonoids, 
phenolic acid, and terpene-rich ethanol extracts from Stevia rebaudiana (candy leaf) and Equisetum arvense (horsetail) inhibited the conidial growth of F. verticillioides; however, they were less effective against the fumonisin production. Extracts of Gynostemma pentaphyllum were observed to inhibit only the growth of $F$. verticillioides $[104,125]$. Recently, for the first time, an experiment has been conducted on stalk rot and reported that synergistic activity of betel leaf extract with B. subtilis TM3 formulation resulted in $20 \%$ inhibition against stem rot disease and $13.37 \%$ against cob rot disease in maize plants [126] (Tables 3 and 4).

\subsection{Plant-Based Essential Oils as Biocontrol Agents}

Plant-based essential oils and their active ingredients play an important role in direct and indirect plant defenses against pathogens and serve as antimicrobial compounds. Essential oils extracted from anise and thyme have been reported to cause complete inhibition of $F$. verticillioides. The growth reduction of $F$. verticillioides was reported up to $79 \%$ by caraway and $86 \%$ by fennel, and more than $60 \%$ inhibition was reported by spearmint, marigold, hazanbul, onynum, basil, and chamomile essential oils at concentration $\leq 500 \mathrm{ppm}$ [127]. Essential oils with certain constituents were extracted from aromatic plants (Aloysia polystachya, Origanum vulgane, Mentha piperita, and Aloysia triphylla) and these oils inhibited growth and fumonisin production in F. verticillioides [128]. Essential oils of lemon grass, cinnamon leaf, clove, palmarosa, and oregano have also been shown to inhibit mycelial growth of $F$. verticillioides, F. proliferatum, and F. gramineareum under different temperature $\left(20-30^{\circ} \mathrm{C}\right)$ and water activity $(0.95-0.995)$ conditions [129]. Furthermore, essential oils from neem, cymbopogon, eucalyptus, clove, peppermint, and cedar wood were screened for their efficacy against Fusarium species in maize and sorghum, and of all the oils tested, citronella from Cymbopogon nardus, at a concentration of $500 \mathrm{ppm}$, inhibited the growth of nine species of Fusarium [130]. Essential oils such as geranial, eugenol, and singerone (oleoresins) extracted from Zingiber officinale exhibited antifungal potential and were reported to be effective against the growth of F. verticillioides [131]. Carvacrol, eugenol, and 2-hexanal (extracted from oregano, thyme, cinnamon, clove, fruits, and vegetables), effectively inhibited the mycelial growth and conidial germination of $F$. verticillioides in maize kernels [99]. Chemical compounds extracted from essential oils, namely eugenol from Syzygium aromaticum, methyl eugenol from Pimenta dioica, and $\alpha$-tumerone and $\beta$-tumerone from Curcuma longa inhibited F. verticillioides growth by $88.70 \%, 53.09,44.20 \%$, and $70.67 \%$, respectively, whereas 1,8-cineole extracted from Rosanium officinalis inhibited conidial production of $F$. verticillioides by $53.48 \%$ [94,100,106]. Recently, essential oils extracted from Anacyclus valentinus, Carum carvil, cinnamon, Cumin cyminum, Cymbopogon nardus, Foeniculum vulgare, Ocimum basilicum, and Thymus capitatus inhibited growth of F. verticillioides from 75 to $92 \%$ by micro and macro dilution methods [132-138] (Tables 3 and 4). Essential oils and their components are important because of their low cost, availability, and wide range of biological activities. Antibacterial and antioxidant abilities of essential oils are well documented but studies on antifungal and antimycotoxigenic abilities of essential oils are still limited [139].

\subsection{Resistant Crops via Breeding as Biocontrol Methods}

The resistant crops grown through genetic engineering and breeding techniques have been designed primarily for avoiding contamination by mycotoxigenic fungi, insect invasion, and mycotoxin detoxification in planta by using gene manipulation studies [140-142]. Transcriptional changes by inoculating $F$. verticillioides among susceptible and resistant genotypes in maize is done by next-generation RNA sequencing [143]. This method provides an important genomic resource in developing disease-resistant maize genotypes [143]. Information on biochemical and molecular methods, elucidating concepts of natural resistance in crops, has become important for further progress in development of resistance to infection by Fusarium and insect infestation in crops [144]. Infection of F. verticillioides in maize indicates up-regulation of genes encoding various ranges of proteins associated with virulence or susceptibility, resistant maize lines, defense, rescue, permatin proteins, patho- 
genesis proteins, proteins scrambled in detoxification response, proteinase inhibitors, and heat shock proteins $[145,146]$. Maize lipoxygenase (ZmLOX) derivative of oxylipins has been identified as contributing to the adaptable plant defense against pathogens. Metabolic activity of lipoxygenase derivatives, including up-regulation of ZmLOX5, LOX genes,

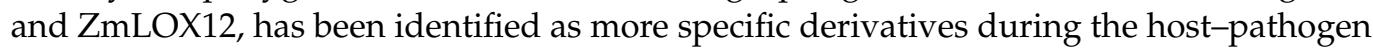
interactions of maize and F. verticillioides [147].

\subsection{Genetic Engineering as Tools for Biocontrol}

Genetic engineering tools improve commercially acceptable crops by certain mechanisms, such as natural, fungal, and insect resistance [142]. Cry proteins from Bacillus thuringiensis (Bt), isolated from Bt maize, were genetically modified and considered as safe to consumers. These cry proteins were highly effective in reducing the level of fumonisin production and insect damage in maize when compared with non-Bt hybrids [148]. Corn borers harm the ear tissue and stalk of maize, stimulating the spore germination of $F$. verticillioides, followed by increased fumonisin production. The vital association of insect damage and total fumonisin level in maize resulted in ear and kernel rot [149]. Similarly, the results of in planta trials in USA and Europe, reported lower fumonisin levels in Bt maize hybrids. Furthermore, such hybrids have been reported to increase the percentage of yield and are environmentally friendly and fit for human and animal consumption as per the World Health Organization (WHO) and the Environmental Protection Agency (EPA) [150]. By lowering fumonisin and aflatoxin contamination in the USA, the annual benefit by Bt maize was reported as USD 23 million [150]. The use of hybrids has become an important tool in developing countries. Bt plants reduce fumonisin production in maize during seasons when the European corn borer (Ostrinia nubilalis Hübner) dominates in the field; however, it is not the case when the corn earthworm (Helicoverpa zea Boddie) dominates the field [149].

\subsection{Commercially Available Products as Biocontrol Agents}

Certain commercial products, other than Bt have been used as biological control agents against Fusarium species: Fusaclean and Biofox $C$ from atoxigenic F. oxysporum strain against $F$. verticillioides in vegetables; Epic and Kodiak from B. subtilis; Intercept from Pseudomonas cepacian; Mycostop from Streptomyces griseoviridis; T-22G, T-22HB, and Biofungus from Trichoderma harzianum; Blue Circle and Deny from Burkholderia cepacian; Cedom and Cerall from Pseudomonas chlororaphis [1]; Novasil and Nevalite from clay material [75]; and Fumzyme from S. macrogoltabida [88]. Although these are biological control agents proven to be environmentally safe, contamination of cereals by F. verticillioides and production of fumonisin continue to be a global threat.

\section{Conclusions}

Additional research data on F. verticillioides, and exposure and safety evaluations of fumonisin are needed to evaluate the potential toxicity of this toxin and its byproducts. Further research on the safety of physical, chemical, and biological decontamination are needed, and specific strategies that combine an integrated decontamination approach must be developed to remove the fumonisin content from cereals and cereal-based foods to the greatest possible extent [151]. Research has been effectively carried out across a wide area to reduce the growth of Fusarium species and fumonisin production during pre-harvest and post-harvest stages by practicing natural and biological methods, including plant materials, minerals, and microorganisms.

Usage of physical methods, even though they seem to be acceptable practices and cause limited change in the properties of the commodity, still seems to be impractical and limiting for large-scale industries as they are time-consuming and expensive. While several of the chemical treatments are affordable and effective against mycotoxins, their use is still banned by the European Union (EU) in food processing, since they can pose certain health risks due to possible toxic byproducts generated. 
From our review, it appears that application of biological methods in lowering the fumonisin production by F. verticillioides, supersedes other measures we have listed, though with a few disadvantages. Microorganisms such as bacteria, fungi, PGPR, probiotics, and atoxigenic strains, even though they are beneficial in minimizing the fumonisin content and cost effective, may become harmful at some stage in their growth and development. Similarly, plant-based natural products such as essential oils, antioxidants, and plant extracts, are derived using certain chemicals, and have been used as a biocontrol agent. Certain essential oils extracted from plants, have shown a wide range of antifungal activities, including minimizing production of fumonisin content by $F$. verticillioides however, it has been reported that the structure obtained after extracting the essential oil appears to be toxic. On the other hand, first-line defense methods, such as development of resistant varieties and application of genetic engineering methods to minimize the production of mycotoxins by fungi, have recently been used, however, only in crops of economic importance.

Resistance to fungal infection by genetic engineering does not seem to be a long-term solution since such varieties are not affordable by most of our farmers. Biological methods, though they are inexpensive and cause no harm to the environment, are time-consuming and impractical in some set-ups. In conclusion, perhaps, additional extensive in vitro and in vivo studies and much more international collaborative research must be initiated on F. verticillioides and production of fumonisin $\mathrm{B} 1$ to add data to the existing knowledge on control measures for this pathogen in the field, at storage, and in the processing period. Such collaboration may lead to a total global control of this fungus and eradication of this carcinogenic toxin in our food chain.

Author Contributions: Conceptualization and writing D.N., supervision, review, and editing M.Y.S., coordinating, editing, correcting, and funding acquisition P.N.A. All authors have read and agreed to the published version of the manuscript.

Funding: This research received no external funding.

Institutional Review Board Statement: Not applicable.

Informed Consent Statement: Not applicable.

Data Availability Statement: Not applicable.

Acknowledgments: We wish to thank the Indian Council of Medical Research (ICMR) to carry out research work on "potential antifungals from PGPR bacteria against fumonisin". We thank Kristen Roberson, graduate writing coach at the Kennesaw State University writing center, Kennesaw, USA, for professional editing of the manuscript.

Conflicts of Interest: The authors confirm that they have no conflict of interest with respect to the work described in this manuscript.

\section{References}

1. Alberts, J.F.; Van Zyl, W.H.; Gelderblom, W.C.A. Biologically Based Methods for Control of Fumonisin-Producing Fusarium Species and Reduction of the Fumonisins. Front. Microbiol. 2016, 7, 548. [CrossRef] [PubMed]

2. Pitt, J.I.; Wild, C.P.; Baan, R.; Gelderblom, W.C.A.; Miller, J.D.; Riley, R. Improving Public Health through Mycotoxin Control; International Agency for Res on Cancer (IARC) Scientific Publication No.; IARC Press: Lyon, France, 2012; 158p.

3. Deepa, N.; Sreenivasa, M.Y. Fumonisin: A review on its Global Occurrence, Epidemiology, Toxicity and Detection. J. Vet. Med. Res. 2017, 4, 1093.

4. Sreenivasa, M.; Diwakar, B.; Raj, A.P.C.; Dass, R.S.; Naidu, K.; Janardhana, G. Determination of toxigenic potential of Fusarium species occurring on sorghum and maize grains produced in Karnataka, India by using Thin Layer Chromatography. Int. J. Life Sci. 2012, 6, 31-36. [CrossRef]

5. $\quad$ Ross, P.F.; Ledet, A.E.; Owens, D.L.; Rice, L.G.; Nelson, H.A.; Osweiler, G.D.; Wilson, T.M. Experimental Equine Leukoencephalomalacia, Toxic Hepatosis, and Encephalopathy Caused by Corn Naturally Contaminated with Fumonisins. J. Veter-Diagn. Investig. 1993, 5, 69-74. [CrossRef] [PubMed]

6. Colvin, B.M.; Harrison, L.R. Fumonisin-induced pulmonary edema and hydrothorax in swine. Mycopathologia 1992, 117, 79-82. [CrossRef] 
7. Voss, K.A.; Riley, R.T.; Snook, M.E.; Waes, J.G. Reproductive and sphingolipid metabolic effects of fumonisin B1 and its alka-line hydrolysis product in LM/Bc mice: Hydrolyzed fumonisin B1 did not cause neural tube defects. Toxicol. Sci. 2009, 112, $459-467$. [CrossRef] [PubMed]

8. Kovacic, S.; Pepeljnjak, S.; Petrinec, Z.; Klarić, M. Fumonisin B1 Neurotoxicity in Young Carp (Cyprinus Carpio L.). Arch. Ind. Hyg. Toxicol. 2009, 60, 419-426. [CrossRef]

9. Thiel, P.G.; Marasas, W.F.O.; Sydenham, E.W.; Shephard, G.S.; Gelderblom, W.C.A. The implications of naturally occurring levels of fumonisins in corn for human and animal health. Mycopathologia 1992, 117, 3-9. [CrossRef] [PubMed]

10. Franceschi, S.; Bidoli, E.; Baron, A.E.; La Vecchia, C. Maize and risk of cancers of the oral cavity, pharynx, and oesophagus in Northeastern Italy. J. Nat. Can. Inst. 1990, 82, 1407-1411. [CrossRef]

11. Chu, F.S.; Li, G.V. Simultaneous occurrence of fumonisin B1 and other mycotoxins in moldy corn collected from People's Re-public of China in regions with high incidence of esophageal cancer. Appl. Environ. Microbiol. 1994, 60, 847-852.

12. Alizadeh, A.M. Fumonisin B1 contamination of cereals and risk of esophageal cancer in a high-risk area in north eastern Iran. Asian Pac. J. Can. Prev. 2012, 13, 2625-2628. [CrossRef]

13. International Agency for Research on Cancer (IARC); World Health Organisation (WHO). Fumonisin B1. In IARC Mono-Graphs on the Evaluation of Carcinogenic Risks to Humans, Some Traditional Herbal Medicines, Some Mycotoxins, Naphthalene and Styrene; IARC Press: Lyon, France, 2002; Volume 82, pp. 301-366.

14. Oren, L.; Ezrati, S.; Cohen, D.; Sharon, A. Early Events in the Fusarium verticillioides-Maize Interaction Characterized by Using a Green Fluorescent Protein-Expressing Transgenic Isolate. Appl. Environ. Microbiol. 2003, 69, 1695-1701. [CrossRef]

15. Desjardins, A.E.; Manandhar, G.; Plattner, R.D.; Maragos, C.M.; Shrestha, K.; McCormick, S. Occurrence of Fusarium Species and Mycotoxins in Nepalese Maize and Wheat and the Effect of Traditional Processing Methods on Mycotoxin Levels. J. Agric. Food Chem. 2000, 48, 1377-1383. [CrossRef]

16. Ghiasian, S.A.; Rezayat, S.M.; Kord-Bacheh, P.; Maghsood, A.H.; Yazdanpanah, H.; Shephard, G.S.; van der Westhuizen, L.; Vismer, H.F.; Marasas, W.F. Fumonisin production by Fusarium species isolated from freshly harvested corn in Iran. Mycopathologia 2005, 159, 31-40. [CrossRef]

17. Munkvold, G.; Stahr, H.M.; Logrieco, A.; Moretti, A.; Ritieni, A. Occurrence of fusaproliferin and beauvericin in Fusariumcontaminated livestock feed in Iowa. Appl. Environ. Microbiol. 1998, 64, 3923-3926. [CrossRef]

18. Mohammadi, A.; Nejad, R.F.; Mofrad, N.N. F. verticillioides from sugarcan, vegetative compatability groups and pathogene-city. Plant Prot. Sci. 2012, 48, 80-84. [CrossRef]

19. Desjardins, A.E.; Busman, M.; Proctor, R.H.; Stessman, R. Wheat kernel black point and fumonisin contamination by Fusarium proliferatum. Food Addit. Cont. 2007, 24, 1131-1137. [CrossRef]

20. Anthony, S.; Abeywickrama, K.; Dayananda, R.; Wijeratnam, S.W.; Arambewela, L. Fungal pathogens associated with banana fruit in Sri Lanka, and their treatment with essential oils. Mycopathologia 2004, 157, 91-97. [CrossRef] [PubMed]

21. Stephens, C.T.; de Vries, R.M.; Sink, K.C. Evaluation of Asparagus species for resistance to Fusarium oxysporoum and Fusarium verticillioides. Horticul. Sci. 1989, 24, 365-368.

22. Corpas-Hervias, C.; Melero-Vara, J.M.; Molinero-Ruiz, L.; Zurera-Muñoz, C.; Basallote-Ureba, M.J. Characterization of Isolates of Fusarium spp. Obtained from Asparagus in Spain. Plant Dis. 2006, 90, 1441-1451. [CrossRef] [PubMed]

23. Tesso, T.; Claflin, L.E.; Tuinstra, M.R. Estimation of Combining Ability for Resistance to Fusarium Stalk Rot in Grain Sorghum. Crop Sci. 2004, 44, 1195-1199. [CrossRef]

24. Rocha, L.D.O.; Reis, G.M.; Da Silva, V.N.; Braghini, R.; Teixeira, M.M.G.; Corrêa, B. Molecular characterization and fumonisin production by Fusarium verticillioides isolated from corn grains of different geographic origins in Brazil. Int. J. Food Microbiol. 2011, 145, 9-21. [CrossRef]

25. Dass, R.S.; Sreenivasa, M.Y.; Charith Raj, A.P.; Janardhana, G.R. PCR-based assay for the rapid detection of Fumonisin-producing Fusarium species in Maize-based animal and poultry feeds in Karnataka, India. Arch. Phytopathol. Plant Prot. 2009, 42, 796-804. [CrossRef]

26. Deepa, N.; Nagaraja, H.; Sreenivasa, M. Prevalence of fumonisin producing Fusarium verticillioides associated with cereals grown in Karnataka (India). Food Sci. Hum. Wellness 2016, 5, 156-162. [CrossRef]

27. Logrieco, A.F.; Mule, G.; Moretti, A.; Bottalico, A. Toxigenic Fusarium Species and Mycotoxins Associated with Maize Ear Rot in Europe. Eur. J. Plant. Pathol. 2002, 108, 597-609. [CrossRef]

28. Covarelli, L.; Stifano, S.; Beccari, G.; Raggi, L.; Lattanzio, V.M.T.; Albertini, E. Characterization of Fusarium verticillioides strains isolated from maize in Italy: Fumonisin production, pathogenicity and genetic variability. Food Microbiol. 2012, 31, 17-24. [CrossRef] [PubMed]

29. Rahjoo, V.; Zad, J.; Javan-Nikkhah, M.; Gohari, A.M. Morphological and molecular identification of Fusarium isolated from maize ears in Iran. J. Plant Pathol. 2008, 90, 463-468.

30. Sreenivasa, M.Y.; Gonzalez Jaen, M.T.; Dass, R.S.; Charithraj, A.P.; Janrdhana, G.R. A PCR based assay for the detetction and differentiation of potential fumonisin producing Fusarium verticillioides isolated from maize kernels. Food Biotechnol. 2008, 22, 160-170. [CrossRef]

31. Qian, G.; Tang, L.; Lin, S.; Xue, K.S.; Mitchell, N.J.; Su, J.; Gelderblom, W.C.; Riley, R.T.; Phillips, T.D.; Wang, J.S. Sequential dietary exposure to aflatoxin B1 and fumonisin B1 in F3 44 rats increases liver preneoplastic changes indicative of a synergistic interaction. Food Chem. Toxicol. 2016, 95, 188-195. [CrossRef] [PubMed] 
32. Nagaraja, H.; Chennappa, G.; Rao, K.P.C.; Prasad, G.M.; Sreenivasa, M.Y. Diversity of toxic and phytopathogenic Fusarium species occurring on cereals grown in Karnataka state, India. 3 Biotech 2016, 6, 57. [CrossRef]

33. Xue, K.S.; Qian, G.; Lin, S.; Su, J.; Tang, L.; Gelderblom, W.C.; Riley, R.T.; Phillips, T.D.; Wang, J.S. Modulation of pre-neoplastic biomarkers induced by sequential aflatoxin B1 and fumnisin B1 exposure in F344 rat treated with UPSN clay. Food Chem. Toxicol. 2018, 114, 316-324. [CrossRef]

34. Kamle, M.; Mahato, D.K.; Devi, S.; Lee, K.E.; Kang, S.G.; Kumar, P. Fumonisins: Impact on Agriculture, Food and Human health and their management strategies. Toxins 2019, 11, 328. [CrossRef]

35. Sreenivasa, M.Y.; Dass, R.S.; Charithraj, A.P.; Janardhana, G.R. Molecular Detection of Fumonisin Producing Fusarium Species of freshly harvested maize kernels using Polymerase Chain Reaction (PCR). Taiwania-Taipei 2006, 51, $251-257$.

36. Deepa, N.; Sreenivasa, M. Biocontrol Strategies for Effective Management of Phytopathogenic Fungi Associated with Cereals. In New and Future Developments in Microbial Biotechnology and Bioengineering-Microbial Biotechnology in Agro-Sustainability; Elsevier: Amsterdam, The Netherlands, 2019; Chapter 13; pp. 177-189. [CrossRef]

37. Deepa, N.; Charith Raj, A.P.; Sreenivasa, M.Y. Multiplex PCR method for the early detection of fumonisin producing Fusarium verticillioides. Food Biosci. 2016, 13, 84-88.

38. Deepa, N.; Adkar-Purushothama, C.R.; Sreenivasa, M.Y. Nested PCR method for the early detection of fumonisin producing Fusarium verticillioides in pure cultures, cereal samples and plant parts. Food Biotechnol. 2016, 30, 18-29.

39. Sreenivasa, M.Y. Fumonisin-A potential carcinogen is of global concern. Res. J. Biotechnol. 2012, 7, 1-2.

40. Deepa, N.; Rakesh, S.; Sreenivasa, M.Y. Morphological, pathological and mycotoxicological variations among Fusarium verticillioides isolated from cereals. 3 Biotech 2018, 8, 105. [CrossRef]

41. Joint FAO WHO Expert Committee on Food Additives, World Health Organization. Safety evaluation of certain food additives and contaminants. In Proceedings of the Seventy Fourth Meetings of the Joint FAO/WHO Expert Committee on Food Additives (JECFA), Rome, Italy, 14-23 June 2011.

42. Miller, J.D. Factors That Affect the Occurrence of Fumonisin. Environ. Health Perspect. 2001, 109, 321. [CrossRef]

43. Sreenivasa, M.Y.; Dass, R.S.; Janardhana, G.R. Survey of post-harvest fungi associated with Sorghum grain produced in Karnatka (India). J. Plant Protect. Res. 2010, 50, 335-339. [CrossRef]

44. Bacon, C.W.; Yates, I.E.; Hinton, D.M.; Meredith, F. Biological control of Fusarium moniliforme in maize. Environ. Health Persp. 2001, 109, 325-332.

45. Bullerman, L.B.; Bianchini, A. Stability of mycotoxins during food processing. Int. J. Food Microbiol. 2007, 119, 140-146. [CrossRef] [PubMed]

46. Whittaker, T.B.; Dickens, W.; Giesbrecht, F.G. Testing animal feedstuffs for mycotoxins: Sampling, subsampling, and analysis. In Mycotoxins and Animal Food; Smith, J.E., Henderson, R.S., Eds.; CRC Press: Boca Raton, FL, USA, 1991; pp. 153-164.

47. Bankole, S.A.; Adebanjo, A. Mycotoxins in food in West Africa: Current situation and possibilities of controlling it. Afr. J. Biotechnol. 2003, 2, 254-263.

48. Bennett, G.A.; Richard, J.L. Influence of processing on Fusarium mycotoxins in contaminated grains. Food Technol. 1996, 50, 235-238.

49. Jackson Di, L.S.; DeVries, J.W.; Bullerman, L.B. Fumonisin in food. In Advances in Experimental Medicine and Biology; Plenum Press: New York, NY, USA, 1996; 392p.

50. Misra, N.N.; Yadav, B.; Roopesh, M.S. Cold plasma for effective fungal and Mycotoxin control in foods: Mechanisms, inac-tivation effects, and applications. Compr. Rev. Food Sci. Food Saf. 2019, 18, 106-120. [CrossRef]

51. Murugesan, P.; Brunda, D.K.; Moses, J.; Anandharamakrishnan, C. Photolytic and photocatalytic detoxification of mycotoxins in foods. Food Control 2020, 123, 107748. [CrossRef]

52. Lopez-Garcia, R.; Park, D.L. Effectiveness of post-harvest procedures in management of mycotoxin hazards. In Mycotoxins in Agriculture and Food Safety; Bhatnagar, D., Sinha, S., Eds.; Marcel Dekker, Inc.: New York, NY, USA, 1998; Volume 511, pp. 407-433.

53. Sreenivasa, M.Y.; Maheshwar, P.K.; Sanjay, S.R.; Diwakar, B.T.; Naidu, K.A.; Janardhana, G.R. Effect of gamma irradiation on the incidence and fumonisin production by Fusarium species occurring on maize and sorghum grains. J. Agric. Technol. 2009, 5, 325-335.

54. Deepthi, B.V.; Gnanaprakash, A.P.; Sreenivasa, M.Y. Effect of $\gamma$-irradiation on fumoniisn producing Fusarium associated with animal and poultry feed mixtures. 3 Biotech 2017, 7, 57. [CrossRef]

55. Pleadin, J.; Frece, J.; Markov, K. Mycotoxins in food and feed. Adv. Food Nutr. Res. 2019, 89, 297-345. [CrossRef] [PubMed]

56. Munkvold, G.P.; Desjardins, A.E. Fumonisin in maize, can we reduce their occurrence? Plant Dis. 1997, 81, 556-565. [CrossRef]

57. Lu, Z.; Dantzer, W.R.; Hopmans, E.C.; Prisk, V.; Cunnick, J.E.; Murphy, P.A.; Hendrich, S. Reaction with Fructose Detoxifies Fumonisin B1while Stimulating Liver-Associated Natural Killer Cell Activity in Rats. J. Agric. Food Chem. 1997, 45, 803-809. [CrossRef]

58. Park, D.L.; Rua, S.M.; Mirocha, C.J.; Abd-Alla, E.S.A.M.; Weng, C.Y. Mutagenic potentials of fumonisin contaminated corn following ammonia decontamination procedure. Mycopathologia 1992, 117, 105-108. [CrossRef] [PubMed]

59. Sydenham, E.W.; Stockenstrom, S.; Thiel, P.G.; Shephard, G.S.; Koch, K.R.; Marasas, W.F.O. Potential of Alkaline Hydrolysis for the Removal of Fumonisins from Contaminated Corn. J. Agric. Food Chem. 1995, 43, 1198-1201. [CrossRef]

60. Scott, P.M.; Lawrence, G.A. Analysis of Beer for Fumonisins. J. Food Prot. 1995, 58, 1379-1382. [CrossRef] 
61. Murphy, P.A.; Hendrich, S.; Hopmans, E.C.; Hauck, C.C.; Lu, Z.; Buseman, G.; Munkvold, G. Effect of Processing on Fumonisin Content of Corn. In Fumonisin in Food; Jackson, L.S., Devries, J.W., Bullerman, L.B., Eds.; Plenum Press: New York, NY, USA, 1996; pp. 323-334.

62. Hendrich, S.; Miller, K.A.; Wilson, T.M.; Murphy, P.A. Toxicity of Fusarium proliferatum-fermented nixtamalized corn-based diets fed to rats: Effect of nutritional status. J. Agric. Food Chem. 1993, 41, 1649-1654. [CrossRef]

63. Dombrink-Kurtzman, M.A.; Javed, T.; Bennett, G.A.; Richard, J.L.; Cote, L.M.; Buck, W.B. Lymphocyte cytotoxicity and erythrocytic abnormalities induced in broiler chicks by fumonisins B1 and B2 and moniliformin from Fusarium proliferatum. Mycopathologia 1993, 124, 47-54. [CrossRef] [PubMed]

64. Park, D.L.; López-García, R.; Trujillo-Preciado, S.; Price, R.L. Reduction of Risks Associated with Fumonisin Contamination in Corn. In Fumonisin in Food; Jackson, L.S., Devries, J.W., Bullerman, L.B., Eds.; Plenum Press: New York, NY, USA, 1996; pp. 335-344.

65. Voss, K.A.; Bacon, C.W.; Meredith, F.I.; Norred, W.P. Comparative subchronic toxicity studies of nixtamalized and water-extracted Fusarium moniliforme culture material. Food Chem. Toxicol. 1996, 34, 623-632. [CrossRef]

66. Schatzmayr, G.; Zehner, F.; Täubel, M.; Schatzmayr, D.; Klimitsch, A.; Loibner, A.P.; Binder, E.M. Microbiologicals for deactivating mycotoxins. Mol. Nut. Food Res. 2006, 50, 543-551. [CrossRef]

67. Visconti, A.; Boenke, A.; Solfrizzo, M.; Pascale, M.; Doko, M.B. European inter comparison study for the determination of the fumonisin content in two maize materials. Food Addit. Cont. 1996, 13, 909-927. [CrossRef]

68. Cavaglieri, L.R.; Andres, L.; Ibanez, M.; Etcheverry, M.G. Rhizobacteria and their potential to control Fusarium verticillioides: Effect of maize bacterization and inoculum density. Antonie van Leeuwenhoek. 2005, 87, 179-187. [CrossRef]

69. Alabouvette, C.; Olivain, C.; Migheli, Q.; Steinberg, C. Microbiological control of soil-borne phytopathogenic fungi with special emphasis on wilt inducing Fusarium oxysporum. New Phytol. 2009, 184, 529-544. [CrossRef]

70. Larkin, R.P.; Fravel, R. Efficacy of various fungal and bacterial biocontrol organisms for control of Fusarium wilt of tomato. Plant Dis. 1998, 82, 1022-1028. [CrossRef] [PubMed]

71. da Cruz Cabral, L.; Pinto, V.F.; Patriarca, A. Application of plant derived compounds to control fungal spoilage and myco-toxin production in food. Int. J. Food Microbiol. 2013, 166, 1-14. [CrossRef] [PubMed]

72. Liu, J.; Sui, Y.; Wisniewski, M.; Droby, S.; Liu, Y. Review: Utilization of antagonistic yeasts to manage postharvest fungal dis-eases of fruit. Int. J. Food Microbiol. 2013, 167, 153-160. [CrossRef] [PubMed]

73. United States Food and Drug Administration (US FDA). RAS Substances Evaluated by Select Committee on GRAS Substances (SCOGS): CFSAN/Office of Food Additive Safety. 2015. Available online: https:/ /www.fda.gov/food/generally-recognizedsafe-gras/gras-substances-scogs-database (accessed on 17 September 2021).

74. Aly, S.E.; Abdel-Galil, M.M.; Abdel-Wahhab, M.A.; Abdel-Wahhab, M.A. Application of adsorbent agents technology in the removal of aflatoxin B1 and fumonisin B1 from malt extract. Food Chem. Toxicol. 2004, 42, 1825-1831. [CrossRef] [PubMed]

75. Robinson, A.; Johnson, N.M.; Strey, A.; Taylor, J.F.; Marroquin-Cardona, A.; Mitchell, N.J. Calcium montmorillonite clay re-duces urinary biomarkers of fumonisin B1 exposure in rats and humans. Food Add. Cont. 2012, 29, 809-818. [CrossRef]

76. Howes, A.D.; Newman, K.E. Compositions and Methods for Removal of Mycotoxins from Animal Feed. U.S. Patent No. 6045834, 4 April 2000.

77. He, J.; Zhou, T. Patented techniques for detoxification of mycotoxins in feeds and food matrices. Recent Pat. Food Nutr. Agric. 2010, 2, 96-104. [CrossRef]

78. Deepa, N.; Sreenivasa, M.Y. Fusarium verticillioides, a globally important pathogen of Agriculture and Livestock: A review. J. Vet. Med. Res. 2017, 4, 1084.

79. Huwig, A.K.; Freimund, S.; Kappeli, O. Mycotoxin detoxification of animal feed by different adsorbents. Toxicol. Lett. 2001, 122, 179-188. [CrossRef]

80. Bacon, C.W.; Hinton, D.M. In planta reduction of maize seedling stalk lesions by the bacterial endophyte Bacillus mojavensis. Can. J. Microbiol. 2011, 57, 485-492. [CrossRef]

81. Cavaglieri, L.; Orlando, J.; Rodríguez, M.I.; Chulze, S.; Etcheverry, M. Biocontrol of Bacillus subtilis against Fusarium verticillioides in vitro and at the maize root level. Res. Microbiol. 2005, 156, 748-754. [CrossRef]

82. Pereira, P.; Sabrina, G.I.; Agostini, E.; Etcheverry, M. Effects of maize inoculation with Fusarium verticillioides and with 2 bac-terial biocontrol agents on seedlings growth and antioxidative enzymatic activities. Appl. Soil Ecol. 2011, 51, 52-59. [CrossRef]

83. Gelderblom, W.; Cawood, M.; Snyman, S.; Vleggaar, R.; Marasas, W. Structure-activity relationships of fumonisins in short-term carcinogenesis and cytotoxicity assays. Food Chem. Toxicol. 1993, 31, 407-414. [CrossRef]

84. Duvick, J.; Rood, T.; Maddox, J.; Gilliam, J. Detoxification of Mycotoxins in Planta as a Strategy for Improving Grain Quality and Disease Resistance: Identification of Fumonisin-Degrading Microbes from Maize. Mol. Gen. Host.-Spec. Toxins Plant Dis. 1998, 13, 369-381. [CrossRef]

85. Duvick, J.; Rood, T.; Wang, X. Fumonisin Detoxification Enzymes. U.S. Patent No. 5716820, 10 February 1998.

86. Blackwell, B.A.; Gilliam, J.T.; Savard, M.E.; Miller, D.; Duvick, J.P. Oxidative deamination of hydrolysed fumonisin B1 (AP1) by cultures of Exophiala spinifera. Nat. Toxins 1999, 7, 31-38. [CrossRef]

87. Cavaglieri, L.; Orlando, J.; Etcheverry, M. In vitro influence of bacterial mixtures on Fusarium verticillioides growth and fumonisin B1 production: Effect of seeds treatment on maize root colonization. Lett. Appl. Microbiol. 2005b, 41, 390-396. [CrossRef] [PubMed] 
88. Heinl, S.; Hartinger, D.; Thamhesl, M.; Vekiru, E.; Krska, R.; Schatzmayr, G.; Moll, W.-D.; Grabherr, R. Degradation of fumonisin B1 by the consecutive action of two bacterial enzymes. J. Biotechnol. 2010, 145, 120-129. [CrossRef] [PubMed]

89. Pereira, P.; Nesci, A.; Castillo, C.; Etcheverry, M. Impact of bacterial biological control agents on fumonisin B1 content and Fusarium verticillioides infection of field-grown maize. Biol. Control 2010, 53, 258-266. [CrossRef]

90. Al-Masri, S.A.; El- Safty, S.M.S.; Nada, S.A.; Amra, H.A. Saccharomyces cerevisiae and Probiotic Bacteria Potentially Inhibit Fumonisin B1 Production in Vitro and in vivo. J. Am. Sci. 2011, 7, 198-205.

91. Cavaglieri, L.; Passone, A.; Etcheverry, M. Screening procedures for selecting rhizobacteria with biocontrol effects upon F. vericillioides growth and fumonisin B1 production. Res. Microbiol. 2004, 155, 747-754. [CrossRef] [PubMed]

92. Fareid, M.A. Biocontrol of Fusarium Moulds and Fumonisin B1 Production. World Rural Obs. 2011, 3, 58-61.

93. Dalie, D.K.D.; Deschamps, A.M.; Atanasova-Penichon, V.; Richard-Forget, F. Potential of Pediococcus pentosaceus (L006) Isolated from Maize Leaf to Suppress Fumonisin-Producing Fungal Growth. J. Food Prot. 2010, 73, 1129-1137. [CrossRef] [PubMed]

94. Gergolet, D.G.; Pizzolitto, R.P.; Vazquex, C.; Usseglio, V.L.; Zunino, M.P.; Dambolena, J.S.; Zygadlo, J.A.; Merlo, C. Effects of the volatile organic compounds produced by Enterococcus spp. Strains isolated from maize grainsilod on Fusarium verticillioides growth and fumonisin B1 production. J. Stored Prod. Res. 2021, 93, 101825. [CrossRef]

95. Calistru, C.; McLean, M.; Berjak, P. In vitro studies on the potential for biological control of Aspergillus flavus and Fusarium moniliforme by Trichoderma species. A study of the production of extracellular metabolites by Trichoderma species. Mycopathologia 1997, 137, 115-124. [CrossRef] [PubMed]

96. Yates, I.E.; Meredith, F.; Smart, W.; Bacon, C.W.; Jaworski, A.J. Trichoderma viride Suppresses Fumonisin B1 Production by Fusarium moniliforme. J. Food Prot. 1999, 62, 1326-1332. [CrossRef]

97. Torres, A.; Ramirez, M.L.; Arroyo, M.; Chulze, S.; Magan, N. Potential use of antioxidants for control of growth and fumonisin production by Fusarium verticillioides and Fusarium proliferatum on whole maize grain. Int. J. Food Microbiol. 2002, 83, 319-324. [CrossRef]

98. Coma, V.; Portes, E.; Gardrat, C.; Richard-Forget, F.; Castellan, A. In vitro inhibitory effect of tetrahydrocurcuminoids on Fusarium proliferatum growth and fumonisin B1 biosynthesis. Food Addit. Cont. 2011, 28, 218-225. [CrossRef]

99. Singh, G.; Kapoor, I.P.S.; Singh, P.; de Heluani, C.S.; de Lampasona, M.P.; Catalan, C.A.N. Chemistry, antioxidant and antimicrobial investigations on essential oil and oleoresins of Zingiber officinale. Food Chem. Toxicol. 2008, 46, 3295-3302. [CrossRef] [PubMed]

100. Menniti, A.; Gregori, R.; Neri, F. Activity of natural compounds on Fusarium verticillioides and fumonisin production in stored maize kernels. Int. J. Food Microbiol. 2010, 136, 304-309. [CrossRef] [PubMed]

101. Huang, X.; Xie, W.; Gong, Z. Antifungal activity of a chitin binding proteins from Ginkgo biloba. FEBS Lett. 2000, 478, 123-126. [CrossRef]

102. Samapundo, S.; De Meulenaer, B.; Osei-Nimoh, D.; Lamboni, L.Y.; Debevere, J.; Devlieghere, F. Can phenolic compounds be used for the protection of corn from fungal invasion and mycotoxin contamination during storage? Food Microbiol. 2007, 24, 465-473. [CrossRef]

103. Beekrum, S.; Govinden, R.; Padayachee, T.; Odhav, B. Naturally occurring phenols: A detoxification strategy for fumonisin B1. Food Addit. Contam. 2003, 20, 490-493. [CrossRef] [PubMed]

104. Garcia, P.; Bainbridge, B.W.; Heala, J.B.; Perez, A.E.; Jimenez, D.R.M. A simple PCR based method for the detection of the chickpea-wilt pathogen Fusarium oxysporum f.sp. ciceris in artificial and natural soils. Eur. J. Plant Pathol. 1999, 105, 251-259. [CrossRef]

105. Deepa, N.; Nayaka, C.S.; Udaya Shankar, A.C.; Krishna Kumar, V.; Niranjana, S.R.; Prakash, H.S.; Raghavendra, M.P. De-tection and management of seed-borne toxigenic Fusarium verticillioides by plant alkaloids. J. Mycol. Plant Pathol. 2012, $42,161-166$.

106. Achimon, F.; Brito, V.D.; Pizzolitto, R.P.; Sanchez, A.R.; Gomez, E.A.; Zydadlor, J.A. Chemical composition and antifungal properties of commercial essential oils against the maize pythopathogenic fungus Fusarium verticillioides. Rev. Argent. Microbiol. 2021, in press.

107. Hermosa, R.; Viterbo, A.; Chet, I.; Monte, E. Plant-beneficial effects of Trichoderma and of its genes. Microbiology 2012, 158, 17-25. [CrossRef]

108. Ali, A.J.; Jubair, A.F.; Mohammadali, M.T. Antifungal activity of Tagetes erecta extract and Trichoderma harzianum on the pathogenic fungus Fusarium verticillioides. Plant Arch. 2020, 20, 185-188.

109. Hinton, D.M.; Bacon, C.W. Enterobacter cloacae is an endophytic symbiont of corn. Mycopathologia 1995, 129, 117-125. [CrossRef]

110. García-Pedrajas, M.D.; Cañizares, M.C.; Sarmiento-Villamil, J.L.; Jacquat, A.G.; Dambolena, J.S. Mycoviruses in Biological Control: From Basic Research to Field Implementation. Phytopathology 2019, 109, 1828-1839. [CrossRef] [PubMed]

111. Yu, J.; Lee, K.M.; Cho, W.K.; Park, J.Y.; Kim, K.H. Differential contributions of RNA interference components in response to distinct Fusarium graminearum virus infectios. J. Virol. 2018, 92, 1756-1772. [CrossRef]

112. Luongo, L.; Galli, M.; Corazza, L.; Meekes, E.; Haas, L.; Plas, L.C. Potential of fungal antagonists for bio-control of Fusarium spp. in wheat and maize through competition in crop debris. Biocontrol Sci. Technol. 2005, 15, 229-242. [CrossRef]

113. Bluhm, B.H.; Kim, H.; Butchko, R.A.E.; Woloshuk, C.P. Involvement of ZFR1 of Fusarium verticillioides in kernel colonization and the regulation of FST1, a putative sugar transporter gene required for fumonisin biosynthesis on maize kernels. Mol. Plant Pathol. 2008, 9, 203-211. [CrossRef] 
114. Rawal, S.; Kim, J.E.; Coulombe, R., Jr. Aflatoxin B1 in poultry: Toxicology, metabolism and prevention. Res. Vet. Sci. 2010, 89, 325-331. [CrossRef] [PubMed]

115. Etcheverry, M.; Torres, A.; Ramirez, M.; Chulze, S.; Magan, N. In vitro control of growth and fumonisin production by Fusarium verticillioides and F. proliferatum using antioxidants under different water availability and temperature regimes. J. Appl. Microbiol. 2002, 92, 624-632. [CrossRef]

116. Farnochi, M.; Torres, A.; Magan, N.; Chulze, S. Effect of antioxidants and competing mycoflora on Fusarium verticillioides and F. proliferatum populations and fumonisin production on maize grain. J. Stored Prod. Res. 2004, 41, 211-219. [CrossRef]

117. Reynoso, M.M.; Torres, A.M.; Ramirez, M.L.; Rodríguez, M.I.; Chulze, S.N.; Magan, N. Efficacy of antioxidant mixtures on growth, fumonisin production and hydrolytic enzyme production by Fusarium verticillioides and F. proliferatum in vitro on maize-based media. Mycol. Res. 2002, 106, 1093-1099. [CrossRef]

118. Roshan, A.B.; Mohana, D.C. Antimicrobial and antimycotoxigenic activities of (3s)-3,6,7-trihydroxy- $\alpha$-tetralone isolated from endophytic Phoma moricola. Pharma Innov. J. 2021, 10, 852-860.

119. Seepe, H.A.; Lodama, K.E.; Sutherland, R.; Nxumalo, W.; Amoo, S.O. In Vivo Antifungal Activity of South African Medicinal Plant Extracts against Fusarium pathogens and Their Phytotoxicity Evaluation. Plants 2020, 9, 1668. [CrossRef]

120. Srichana, D.; Phumruang, A.; Chongkid, B. Inhibition Effect of Betel Leaf Extract on the Growth of Aspergillus flavus and Fusarium verticillioides Thammasat. Ind. J. Sci. Technol. 2009, 14, 74-77.

121. Yooussef, M.M.; Pham, Q.; Achar, P.N.; Sreenivasa, M.Y. Antifungal activity of essential oils on Aspergillus parasiticus isolated from peanuts. J. Plant. Prot. Res. 2016, 56, 139-142. [CrossRef]

122. Hell, K.; Cardwell, K.; Setamou, M.; Poehling, H.-M. The influence of storage practices on aflatoxin contamination in maize in four agroecological zones of Benin, west Africa. J. Stored Prod. Res. 2000, 36, 365-382. [CrossRef]

123. Dambolena, J.; Zygadlo, J.A.; Rubinstein, H. Antifumonisin activity of natural phenolic compounds: A structure-property-activity relationship study. Int. J. Food Microbiol. 2011, 145, 140-146. [CrossRef]

124. Ferrari, S.; Vairo, D.; Ausubel, F.M.; Cervone, F.; De Lorenzo, G. Tandemly duplicated Arabidopsis genes that encode polygalacturonase-inhibiting proteins are regulated coordinately by different signal transduction pathways in response to fungal in-fection. Plant Cell Online 2003, 15, 93-106. [CrossRef]

125. Srichana, D.; Taengtip, R.; Kondo, S. Antimicrobial activity of Gynostemma pentaphyllum extracts against fungi producing aflatoxin and fumonisin and bacteria causing diarrheal disease. Southeast Asian J. Trop. Med. Public Health 2011, 42, 704. [PubMed]

126. Sebayang, A.; Mirsam, H.; Pakki, S.; Azrai, M.; Muis, A. Control of Fusarium verticillioides on corn with a combination of B. subtilis TM3 formulation and botanical pesticides. Saudi J. Bio. Sci. 2021, in press. [CrossRef]

127. Soliman, K.; Badeaa, R. Effect of oil extracted from some medicinal plants on different mycotoxigenic fungi. Food Chem. Toxicol. 2002, 40, 1669-1675. [CrossRef]

128. López, A.G.; Theumer, M.G.; Zygadlo, J.A.; Rubinstein, H.R. Aromatic plants essential oils activity on F. verticillioides fumonsin B1 production in corn grains. Mycopathologia 2004, 158, 343-349. [CrossRef] [PubMed]

129. Velluti, A.; Sanchis, V.; Ramos, A.J.; Egido, J.; Marin, S. Inhibitory effect of cinnamon, clove, lemongrass, oregano and pal-marose essential oils on growth and fumonisin B1 production by Fusarium proliferatum in maize grain. Int. J. Food Microbiol. 2003, 89, 145-154. [CrossRef]

130. Nagendra Prasad, M.N.; Shankara Bhat, S.; Sreenivasa, M.Y. Antifungal activity of essential oils against Phomopsis azadirachtaethe causative agent of die-back disease of neem. J. Agric. Technol. 2010, 6, 27-133.

131. Sreenivasa, M.Y.; Dass, R.S.; Charithraj, A.P.; Premila, N.A.; Janardhana, G.R. Assessment of the growth inhibiting effect of some plant essential growth inhibiting effect of some plant essential oils on different Fusarium species isolated from Sorghum and maize grains. J. Plant Dis. Protect. 2011, 118, 208-213. [CrossRef]

132. López-Meneses, A.K.; Plascencia-Jatomea, M.; Lizardi-Mendoza, J.; Rosas-Burgos, E.C.; Luque-Alcaraz, A.G.; Cortez-Rocha, M.O. Anti-fungal and antimycotoxigenic activity of essential oils from Eucalyptus globulus, Thymus capitatus and Schinus molle. Food Sci. Technol. 2015, 35, 664-671. [CrossRef]

133. Houicher, A.; Hamdi, M.; Hechachna, H.; Özogul, F. Chemical composition and antifungal activity of Anacyclus valentinus essential oil from Algeria. Food Biosci. 2018, 25, 28-31. [CrossRef]

134. Zabka, M.; Pavela, R.; Slezakova, L. Antifungal effect of Pimenta dioica essential oil against dangerous pathogenic and toxinogenic fungi. Ind. Crops Prod. 2009, 30, 250-253. [CrossRef]

135. Xing, F.; Hua, H.; Selvaraj, J.N.; Zhao, Y.; Zhou, L.; Liu, X.; Liu, Y. Growth inhibition and morphological alterations of Fusarium verticillioides by cinnamon oil and cinnamaldehyde. Food Control 2014, 46, 343-350. [CrossRef]

136. Sharifzadeh, A.; Javan, A.J.; Shokri, H.; Abbaszadeh, S.; Keykhosravy, K. Evaluation of antioxidant and antifungal proper-ties of the traditional plants against foodborne fungal pathogens. J. Mycol. Med. 2016, 26, e11-e17. [CrossRef]

137. Davari, M.; Ezazi, R. Chemical composition and antifungal activity of the essential oil of Zhumeria majdae, Heracleum persicum and Eucalyptus sp. against some important phytopathogenic fungi. J. Mycol. Med. 2017, 27, 463-468. [CrossRef]

138. Dambolena, J.; Zunino, M.; López, A.G.; Rubinstein, H.; Zygadlo, J.A.; Mwangi, J.W.; Thoithi, G.N.; Kibwage, I.; Mwalukumbi, J.M.; Kariuki, S.T. Essential oils composition of Ocimum basilicum L. and Ocimum gratissimum L. from Kenya and their inhibitory effects on growth and fumonisin production by Fusarium verticillioides. Innov. Food Sci. Emerg. Technol. 2010, 11, 410-414. [CrossRef] 
139. Ingok, A.M.; Devoglu, D.; Dikmetas, N.; Karbancioglu-Guler, F.; Capanoglu, E. Antibacterial, antifungal, antimycotoxigenic, antioxidant activities of essential oils: An updated review. Molecules 2020, 25, 4711. [CrossRef]

140. Duvick, J. Prospects for reducing fumonisin contamination of maize through genetic modification. Environ. Health Persp. 2001, 109, 337-342.

141. Cleveland, T.E.; Dowd, P.F.; Desjardins, A.E.; Bhatnagar, D.; Cotty, P.J. United States Department of Agriculture? Agricultural Research Service research on pre-harvest prevention of mycotoxins and mycotoxigenic fungi in US crops. Pest. Manag. Sci. 2003, 59, 629-642. [CrossRef]

142. Lanubile, A.; Ferrarini, A.; Maschietto, V.; Delledonne, M.; Marocco, A.; Bellin, D. Functional genomic analysis of constitutive and inducible defense responses to Fusarium verticillioides infection in maize genotypes with contrasting ear rot resistance. $B M C$ Genom. 2014, 15, 1-16. [CrossRef] [PubMed]

143. Schnable, P.S.; Ware, D.; Fulton, R.S.; Stein, J.C.; Wei, F.; Pasternak, S.; Liang, C.; Zhang, J.; Fulton, L.; Graves, T.A.; et al. The B73 Maize Genome: Complexity, Diversity, and Dynamics. Science 2009, 326, 1112-1115. [CrossRef] [PubMed]

144. Alessandra, L.; Luca, P.; Adriano, M. Differential gene expression in kernels and skills of maize lines with contrasting levels of ear rot resistance after Fusarium verticillioides infection. J. Plant Physiol. 2010, 167, 1398-1406. [CrossRef] [PubMed]

145. Maschietto, V.; Marocco, A.; Malachova, A.; Lanubile, A. Resistance to Fusarium verticillioides and fumonisin accumulation in maize inbred lines involves an earlier and enhanced expression of lipoxygenase (LOX) genes. J. Plant Physiol. 2015, 188, 9-18. [CrossRef] [PubMed]

146. Butròn, A.; Santiago, R.; Mansilla, P.; Pintos-Varela, C.; Ordás, A.; Malvar, R.A. Maize (Zea mays L.) Genetic factors for pre-venting fumonisin contamination. J. Agric. Food Chem. 2006, 54, 6113-6117. [CrossRef]

147. Dowd, P.F. Biotic and abiotic factors limiting efficacy of Bt corn in indirectly reducing mycotoxin levels in commercial fields. $J$. Econ. Ėntomol. 2001, 94, 1067-1074. [CrossRef] [PubMed]

148. Hammond, B.G.; Campbell, K.W.; Pilcher, C.D.; DeGooyer, T.A.; Robinson, A.E.; McMillen, B.L.; Spangler, S.M.; Riordan, S.G.; Rice, L.G.; Richard, J.L. Lower Fumonisin Mycotoxin Levels in the Grain of Bt Corn Grown in the United States in 2000-2002. J. Agric. Food Chem. 2004, 52, 1390-1397. [CrossRef]

149. International Programme on Chemical Safety (IPCS). Environmental Health Criteria 217: Microbial Pest Control Agent Bacillus Thuringiensis; World Health Organisation (WHO): Geneva, Switzerland, 1999.

150. Wu, F. Mycotoxin Reduction in Bt Corn: Potential Economic, Health, and Regulatory Impacts. Transgenic Res. 2006, 15, 277-289. [CrossRef] [PubMed]

151. Daou, R.; Joubrane, K.; Maroun, R.G.; Khabbaz, L.R.; Ismail, A.; El Khoury, A. Mycotoxins: Factors influencing production and control strategies. AIMS Agric. Food 2021, 6, 416-447. [CrossRef] 